\title{
Children of men ...
}

There is a recurring theme in apocalypse fiction - and I am not talking about famine or war. It is infertility. I have often wondered why, probably because having lived most of my life in the developing world, it is something I have seldom come across. However, recent studies suggest that in the developed world, scenarios such as those painted in Children of Men and The Handmaid's Tale may well come to pass.

A study from the Hebrew University of Jerusalem published recently in Human Reproduction Update ${ }^{[1]}$ shows that sperm counts among men in the developed world have more than halved during the past 40 years and are currently falling by around $1.4 \%$ per year. The research drew on 185 studies conducted between 1973 and 2011, involving around 43000 men. The team found that sperm concentration fell from 99 million per $\mathrm{mL}$ in 1973 to 47.1 million per $\mathrm{mL}$ in 2011 - a drop of $52.4 \%$. In the same group, the total sperm count dropped by just under $60 \%$.

Are people worried about this? Apparently they are, with the World Health Organization describing current knowledge of male infertility as 'very low'. This was also the stance of the UK Medical Research Council, which has called for those in the field to put projects forward for funding. The situation is complicated by the fact that more and more couples in the developed world delay childbearing into their 30s, when the likelihood of conception is lower anyway. ${ }^{[2]}$

The causes are so far unknown, but just about everything, from cell phones, to smoking, to oral contraceptives contaminating drinking water, has been blamed. But should we really be worried? Not entirely flippantly, I would suggest that this is a good reason for European countries (and indeed those of the Antipodes) to stop their 'fortress' approach to immigration from the developing world. Not only do they have top-heavy, ageing populations, but now their fertility is also declining. These countries need young immigrants - those from the Middle Eastern countries are often highly qualified, able to fill skill gaps in the ageing European populations, while others are all too willing to work in areas that local youngsters decline So, not only would immigration change the age structure of these populations, but, until the immigrants too are smitten by whatever is dropping fertility, they will provide more fertile populations as well. My previous training in population biology now comes to the fore - this shows all too well that humankind is simply another biological population, subject to the vagaries of our environment. We forget this at our peril!

\section{Bridget Farham}

Editor

ugqirha@iafrica.com

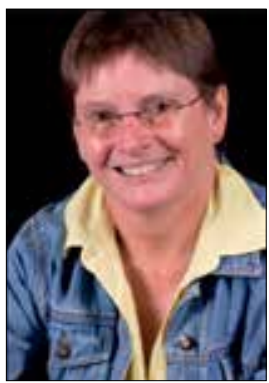

1. Levine $\mathrm{H}$, Jørgensen $\mathrm{N}$, Martino-Andrade A, et al. Temporal trends in sperm count: A systematic review and meta-regression analysis. Hum Reprod Update 2017 (epub 2 August 2017). https://do. org $10.1093 /$ humupd/dmx022

2. The Guardian. The infertility crisis is beyond doubt: Now scientists must find the cause. https://Www. theguardian.com/science/2017/jul/29/infertility-crisis-sperm-counts-halved (accessed 14 August 2017).

S Afr Med J 2017;107(9):721. DOI:10.7196/SAMJ.2017.v107i9.12799 